EESTI NSV TEADUSTE AKADEEMIA TOIMETISED. 27. KOIDE

KEEMIA. 1978, NR. 1

ИЗВЕСТНЯ АКАДЕМИИ НАУК ЭСТОНСКОЙ ССР. ТОМ 27 Химия. 1978, № 1

Лиа НАППА, А. ФОМННА,

удК 662.67 .550 .4

Э. КИВИМЯГИ|, Марет КУУЗИК

\title{
ОБ АЗОТЕ КЕРОГЕНА ГРАПТОЛИТОВОГО АРГИЛЛИТА СЕВЕРНОЙ ЭСТОНИИ
}

Граптолитовые аргиллиты (диктионемовые сланцы) тюрисалуской пачки пакерортского горизонта нижнего ордовика залегают непосредственно на фосфоритоносных песчаниках Северной Эстонии, вследствие чего при открытой добыче фосфоритов они оказываются вскрышными, и целесообразно их практически использовать.

Литологические исследования аргиллитов показали, что нेа относительно узкой площади Северо-Восточной Эстонии они образовались в несколько иных фациальных условиях, чем на обширной площади Западной Эстонии. Кроме того, изучением остатков фауны доказано, что аргиллиты разных фаций имеют и разный возраст [1]. Аргиллиты восточной фации моложе, чем аргиллиты западной. Они содержат также больше алевритовых прослоек, чем однородные аргиллиты западной фации. Но по суммарному содержанию общего керогена существенной разницы между разновозрастными аргиллитами тюрисалуской пачки не обнаружено.

Кероген граптолитовых аргиллитов Северной Эстонии характеризуется относительно высоким содержанием азота $(2-4 \%)$, что говорит о его возможном происхождении из органического вещества [ $\left.{ }^{2}\right]$.

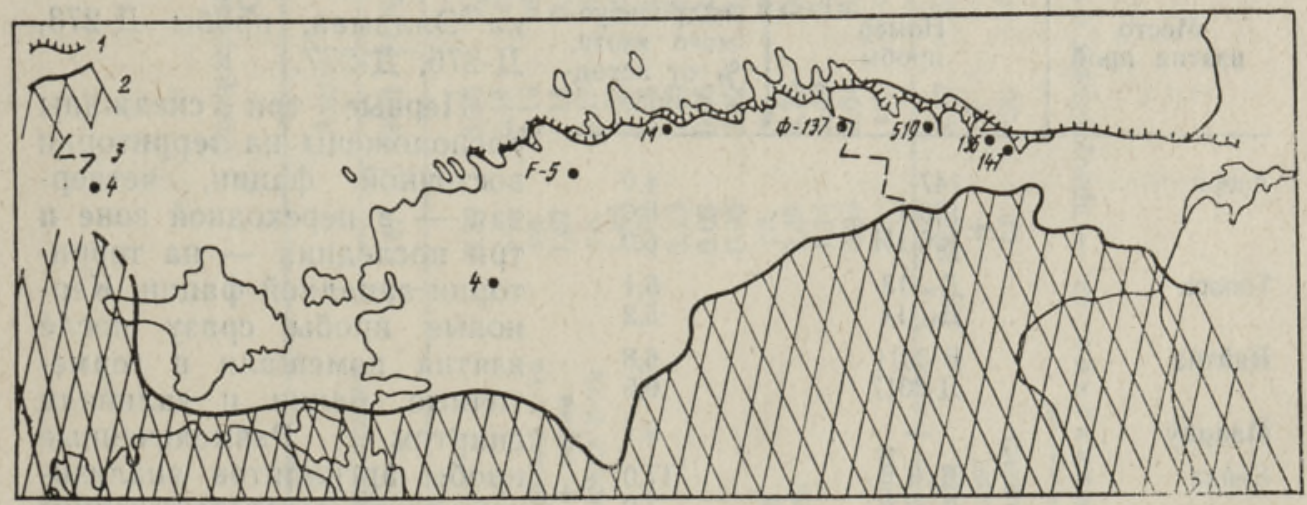

Распространение аргиллитов и места взятия проб.

1 - глинт, 2 - область, где аргиллиты не распространяются, 3 - граница между западной и восточной фациями, 4 - места отбора проб и их номера. 
Характеристика разных проб диктионемового сланца Северной Эстонии после обработки $5 \%$-ной соляной кислотой

\begin{tabular}{|c|c|c|c|c|c|c|c|}
\hline \multirow{2}{*}{$\begin{array}{l}\text { Место } \\
\text { взятия } \\
\text { проб }\end{array}$} & \multirow[b]{2}{*}{$\begin{array}{l}\text { Номер } \\
\text { пробы }\end{array}$} & \multirow[b]{2}{*}{$\begin{array}{c}\text { Влага, } \\
\%\end{array}$} & \multirow[b]{2}{*}{$\begin{array}{c}\text { Зола, } \\
\%\end{array}$} & \multicolumn{4}{|c|}{ Элементарный состав, \% } \\
\hline & & & & $\mathrm{C}$ & $\mathrm{H}$ & $\mathrm{N}$ & $\begin{array}{c}\text { гетеро- } \\
\text { атомы (по } \\
\text { разности) }\end{array}$ \\
\hline Азери & $\begin{array}{l}136-\mathrm{I} \\
136-\mathrm{III} \\
147\end{array}$ & $\begin{array}{l}1,1 \\
1,4 \\
1,1\end{array}$ & $\begin{array}{l}78,5 \\
79,1 \\
79,8\end{array}$ & $\begin{array}{l}64,2 \\
67,0 \\
65,3\end{array}$ & $\begin{array}{l}6,5 \\
6,9 \\
6,9\end{array}$ & $\begin{array}{l}1,6 \\
2,3 \\
2,2\end{array}$ & $\begin{array}{l}27,7 \\
23,8 \\
25,6\end{array}$ \\
\hline Тоолсе & $\begin{array}{l}Д_{\mathrm{M}}-13 \\
\text { Д }_{\mathrm{M}}-14\end{array}$ & $\begin{array}{l}1,4 \\
0,6\end{array}$ & $\begin{array}{l}78,1 \\
76,4\end{array}$ & $\begin{array}{l}72,1 \\
71,4\end{array}$ & $\begin{array}{l}8,1 \\
7,0\end{array}$ & $\begin{array}{l}1,9 \\
1,9\end{array}$ & $\begin{array}{l}19,8 \\
19,7\end{array}$ \\
\hline Вийтна & $\begin{array}{l}\text { В-3011 } \\
\text { Д-3017 }\end{array}$ & $\begin{array}{l}1,2 \\
0,5\end{array}$ & $\begin{array}{l}91,4 \\
78,0\end{array}$ & $\begin{array}{l}70,5 \\
62,6\end{array}$ & $\begin{array}{l}8,0 \\
7,0\end{array}$ & $\begin{array}{l}0,8 \\
1,5\end{array}$ & $\begin{array}{l}20,7 \\
28,9\end{array}$ \\
\hline Маарду & & 1,8 & 81,7 & 64,9 & 7,4 & 2,2 & 25,5 \\
\hline Кейла & $\begin{array}{l}Д_{0}-1 \\
Д_{0}-3 \\
\text { Д }_{0}-5\end{array}$ & $\begin{array}{l}1,1 \\
1,2 \\
1,2\end{array}$ & $\begin{array}{l}84,6 \\
81,7 \\
80,7\end{array}$ & $\begin{array}{l}66,5 \\
69,9 \\
67,4\end{array}$ & $\begin{array}{l}7,6 \\
8,0 \\
7,8\end{array}$ & $\begin{array}{c}2,2 \\
3,5 \\
\text { He on }\end{array}$ & $\begin{array}{r}23,7 \\
18,6 \\
\text { деляли }\end{array}$ \\
\hline Әлламаа & $\begin{array}{l}\text { Д-273 } \\
\text { Д-275 } \\
\text { Д-277 }\end{array}$ & $\begin{array}{l}1,1 \\
1,0 \\
1,0\end{array}$ & $\begin{array}{l}80,9 \\
78,8 \\
74,8\end{array}$ & $\begin{array}{l}63,7 \\
74,4 \\
66,4\end{array}$ & $\begin{array}{l}7,9 \\
9,0 \\
6,8\end{array}$ & $\begin{array}{l}1,5 \\
1,7 \\
1,8\end{array}$ & $\begin{array}{l}28,4 \\
14,6 \\
26,8\end{array}$ \\
\hline
\end{tabular}

Целью настоящего исследования было изучение химической природы азота керогена разновозрастных аргиллитов, отобранных из разных уровней тюрисалуской пачки.

Для лабораторных исследований взяты 14 керновых проб из следующих мест (рисунок): 1) скв. 136, месторождение Азери, пробы 136/I, 136/III; 2) скв. 147, месторождение Азери, проба 147; 3) скв. 519, месторождение Тоолсе, пробы Дам-13, Д $\mathbf{M}^{-14}$; 4) скв. Ф137, около поселка

Таблица 2

Количество гидролизуемого азота и его формы

\begin{tabular}{|c|c|c|}
\hline $\begin{array}{c}\text { Место } \\
\text { взятия проб }\end{array}$ & $\begin{array}{l}\text { Номер } \\
\text { пробы }\end{array}$ & $\begin{array}{c}\text { Количество } \\
\text { гидролизуе- } \\
\text { мого азота, } \\
\% \text { от исход- } \\
\text { ного }\end{array}$ \\
\hline
\end{tabular}

\begin{tabular}{|c|c|}
\hline Азери & $\begin{array}{l}147 \\
136-\mathrm{I} \\
136-\mathrm{III}\end{array}$ \\
\hline Тоолсе & $\begin{array}{l}\text { Д }_{M}-13 \\
\text { Д }_{M}-14\end{array}$ \\
\hline Вийтна & $\begin{array}{l}\text { В-3011 } \\
\text { Д-3017 }\end{array}$ \\
\hline Маарду & - \\
\hline Кейла & $\begin{array}{l}Д_{0}-1 \\
\text { Д̆}_{0}-3 \\
\text { Д}_{0}-5\end{array}$ \\
\hline Элламаа & $\begin{array}{l}\text { Д-273 } \\
\text { Д-275 } \\
\text { Д-277 }\end{array}$ \\
\hline
\end{tabular}
Вийтна, пробы В-3011, Д-3017; 5) карьер месторождения Маарду, одна общая проба; 6$)$ скв. $F-5$, около г. Кейла, пробы Д Д $0-5 ; 7)$ скв. 4 , около поселка Элламаа, пробы Д-273, Д-275, Д-277.

Первые три скважины расположены на территории восточной фации, четвертая - в переходной зоне и три последних - на территории западной фации. Керновые пробы сразу после взятия помещали в герметичные банки и заливали спиртом. Размельченные пробы аргиллитов анализировали по соответствующим ГОСТам (табл. 1).

Гидролиз проб проводили при температуре $105 \pm 2{ }^{\circ} \mathrm{C}$ 


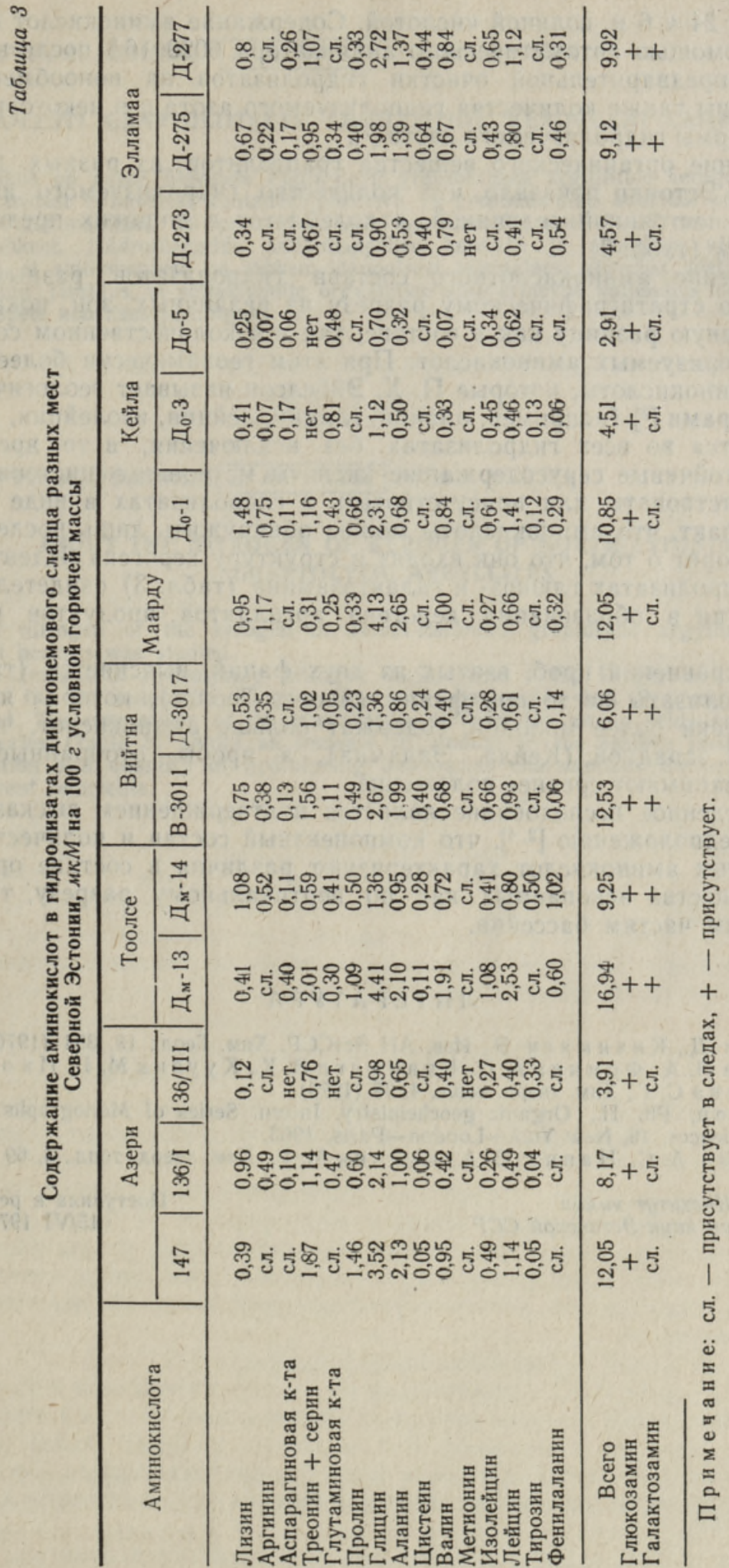


в течение 24 ч 6 н. соляной кислотой. Содержание аминокислот определяли с помощью автоматического анализатора 6020 16А после выпаривания и предварительной очистки гидролизатов на ионообменниках. Определены также количества гидролизуемого азота и в некоторых пробах - формы гидролизуемого азота [ $\left.{ }^{2}\right]$.

Изучение органического вещества граптолитов из разных пунктов Северной Эстонии показало, что количество гидролизуемого азота не является постоянной величиной, а колеблется в широких пределах от 4,0 до $17 \%$ (табл. 2).

Сравнение аминокислотного состава гидролизатов разных проб, взятых по стратиграфическому разрезу из различных зон, показывает определенную разницу как в составе, так и в количественном содержании гидролизуемых аминокислот. При этом геохимически более устойчивые аминокислоты, которые П. Х. Эйбелсон называет геологическими термометрами [3] (например, аланин, глицин, лейцин, изолейцин, валин), встречаются во всех гидролизатах без исключения, в то время как менее устойчивые серусодержащие кислоты метионин и цистеин могут или отсутствовать, или присутствовать в гидролизатах в виде следов.

Сам факт, что аминокислоты можно обнаружить лишь после гидролиза, говорит о том, что они входят в структуру керогена. Идентификация в гидролизатах глюкоз- и галактозамина (табл. 3) свидетельствует об участии в образовании керогена аргиллитов продуктов распада хитина.

При сравнении проб, взятых из двух фаций, выясняется (табл. 3), что гидролизаты восточной фации (Азери, Тоолсе), которая является геологически более молодой, содержат больше аминокислот, чем гидролизаты западной (Кейла, Элламаа), а пробы, отобранные около Вийтна, занимают среднее положение.

Проведенное исследование является подтверждением высказанному ранее предположению $[2,4]$, что компонентный состав и количество гидролизуемых аминокислот характеризуют различия в составе органического вещества ископаемых как по вертикальному разрезу, так и по различным частям бассейна.

\section{Л И ТЕРА Т У Р А}

1. Кальо Д., Ки ви м яги Э., Изв., АН ЭстССР. Хим. Геол., 19, 334 (1970).

2. Н ап п а Л. А., Фомин а А. С., Ки ви мяги Э. К., Куузик М. Г., Иконопис ц е в а С. Г., Хим. тверд. топл., 4, 98 (1975).

3. Abelson, Ph. H., Organic geochemistry, Intern. Series of Monographs of Earth Sciences, 16, New York-London-Paris, 1963.

4. Фомина А. С., Н апп а Л. А., Куузик М. Г., Хим. тверд. топл., 4, 69 (1973).

Институт химии
Академии наук Эстонской ССР
Поступила в редакцию 15/VI 1976 
Lia NAPPA, A. FOMINA, E. KIVIMAGI , Maret KUUSIK

\section{POHJA-EESTI GRAPTOLIITSETE ARGILLIITIDE KEROGEENI LAMMMASTIKUST}

Artiklis on antud ülevaade Põhja-Eesti graptoliitsete argilliitide kerogeeni lämmastiku vormidest erinevatest kohtadest pärineva 14 puursüdamiku analüüsi pōhjal. Hüdrolüüsuvat lämmastikku oli proovides $4-17 \%$. Identifitseeriti $8-17$ aminohapet ja 2 aminosuhkrut. Hüdrolüsaatide aminohappelise koostise ja sisalduse võrdlus näitas (tab. 3), et aminohappeid on rohkem idapoolsest fatsiaalsest vööndist vōetud proovides. On tehtud järeldus, et settekivimite orgaanilise aine erinevus väljendub hüdrolüüsuvate aminohapete koostises ja hulgas.

Lia NAPPA, A. FOMINA, E. KIVIMAGI , Maret KUUSIK

\section{ABOUT THE NITROGEN OF KEROGEN OF NORTH-ESTONIAN GRAPTOLYTIC ARGYLLITES}

The nitrogen of the kerogen of North-Estonian graptolytic argyllites from 13 different borings was studied.

The amount of hydrolyzing nitrogen varies from 4 till 17 per cent in different samples. On an automatic aminoanalyzer, 17 aminoacids and 2 aminosugars were identified. The comparison of the quantitative data on the amino acids present in the hydrolysates (Table 3 ) shows an increase in amount in the eastern facial zone. The composition and quantity of hydrolyzing aminoacids characterizes the organic matter of different sediments. 